\title{
WINTER QUARTERLY MEETING 1980
}

The Winter Quarterly Meeting and the Maudsley Bequest lectures were held at the Royal Society of Medicine on 5 and 6 February, 1980, under the Presidency of Professor Desmond Pond.

\section{Monday 4 February}

\section{Scientific Meetings}

The Fourteenth Blake Marsh Lecture, entitled, 'Injury and Insult-Considerations of the Neuropathological Aetiology of Mental Subnormality', was given by Dr Valerie Cowie at the Medical Society of London. Dr J. Jancar gave the vote of thanks.

\section{Twesday 5 February: Mandsley Bequest lectures}

Recent Advances in Behavioural Psychotherapy-Professor Isaac Marks

Drug Behavioural Interactions in Phobic and ObsessiveCompulsive Disorders-Dr R. S. Stern

How Should We Define Schizophrenia?-Professor R. E. Kendell

The Implications of a Changing Diagnosis in Psychiatry: Schizophrenia Succeeded by Affective Disorders-Dr E. Carol Sheldrick

The Transformation of Psychiatry by Recent Advances in Pharmacology - Dr Marthe Vogt

Growth Points in the Study of Dementia-Sir Martin Roth

Neuroendocrine Approaches to Psychiatric Disease-Dr Stuart Checkley

Wedhesday 6 February: Maudsley Bequest lectures

Psychoses of Epilepsy-Dr Brian Toone

Psychopharmacological Aspects of Epilepsy-Dr E.H. Reynolds

Some Medico-Legal Problems Posed by EpilepsyProfessor J. Gunn

Hysteria-Professor A. C. P. Sims

The Management of Anorexia Nervosa and BulimiaProfessor G. F. M. Russell

Social Factors in Depression-Dr Alec Roy

The Treatment of Depressive Illness in General PracticeDr Joan Thomson

Recent Research in Depression-Professor E. S. Paykel

\section{Other Sessions}

The Section for the Psychiatry of Old Age held a conference on 4 February on 'Development in Training and Research'. The opening sessions examined the training of doctors and the contribution of other disciplines, and in the afternoon, sessions were devoted to the evaluation of services and progress in research.

At the Dependence/Addiction Group meeting on 5
February two papers were presented, 'Nicotine Dependence and Tobacco Smoking' by Dr C. Kumar and 'Drug Dependence the Failure of Treatment' by Dr M. Gossop.

Dr J. Kauber gave a talk on 'A Psychoanalyst's Thoughts about Psychoanalysis' at the Psychotherapy Section meeting on 5 February.

\section{Business Meeting \\ The Business Meeting was held on Wednesday 6} February.

Minutes

The Minutes of the previous meeting held on 16 November 1979 and published in the Bulletin, January 1980 were approved and signed.

\section{OBITUARY}

The Registrar announced with regret the death of the following members:

Jashabant Parmar, Dandenong Psychiatric Centre, Dandenong, Australia.

Mazhar Hussain Shah, Lt. Col., Naveed Clinic, Karachi, Pakistan.

JoY Evelyn West, Assistant Psychiatrist, Wallington Day Hospital, Cheam, Surrey.

\section{REgistraR'S REPORT}

Dr GeRAlD TimbURY presented the Registrar's report:

'The Executive and Finance Committee has met on three occasions since my last report on 16 November. The Court of Electors met on 10 December and Council met on 16 January. Council noted with pleasure that Professor W. H. Trethowan had been awarded a Knighthood in the New Year's Honours List. Drs J. Leff and B. Morris were welcomed as the Council representatives of the new Social and Community Psychiatry Section.

The College has received an encouraging reply from $\mathrm{Mr}$ Patrick Jenkin, Secretary of State for the Social Services, to the President's letter asking that priority for the development of the mental health services should be maintained. [Mr Jenkin's letter appears in the February Bulletin, p. 32.]

College Divisions and Sections have been asked to submit comments on the consultative document 'Patients First' and a Special Committee will meet on 13 March to discuss these comments.

A College comment on the discussion document 'Marriage Matters' has been agreed by Council and will be published in the Bulletin [published in March issue].

Council has discussed the question of the sponsorship of College meetings by the pharmaceutical industry, and notes 
of guidance are being prepared. It is suggested that wherever possible sponsorship should be used to improve the scientific quality of meetings rather than to provide lavish social functions.

Council has approved an amendment to the Regulations which will allow Honorary Fellows to be elected at Quarterly Meetings [see this issue page 65] in order to avoid the potentially embarrassing situation where Honorary Fellows are elected at the Annual Meeting immediately before their formal admission to the College.

The Mental Deficiency Section have prepared a discussion document on some of the problems facing the specialty, and this document will be published in the Bulletin in the near future. [See this issue page 61].

The Court of Electors confirmed the results of the recent Preliminary Test and Membership Examination. There were 159 successful candidates in the Preliminary Test and 137 candidates passed the Membership. (Pass rates of 52 per cent and 55 per cent respectively.) The College understands that it is possible that the London Conjoint DPM may be phased out. The Court of Electors and other major College committees will consider whether there might be a place for a College Diploma in Psychiatry which would be suitable for candidates not wishing to become consultant psychiatrists in the NHS, or for other specialties, for example, general practitioners or geriatric physicians who might desire a qualification to confirm their knowledge and experience of psychiatric work.

A useful meeting of Secretaries of Divisions, Sections and Groups was held on 16 January, when arrangements to extend and co-ordinate activities were discussed.

Following the last meeting of Council, a discussion on Medical Audit was opened by Dr D. H. Dick, Director of the Health Advisory Service. A discussion paper on this important topic is being prepared for the Bulletin and it seems likely that this subject and all its ramifications will engage the attention of many College members in the next few years. The DHSS report 'Organizational and Management Problems of Mental Illness Hospitals' was published on 22 January. It is intended that this report should be discussed by Council at its next meeting, and it is hoped that the views of Divisions and Sections on the document will be forwarded in the course of the next few months.

Arrangements for the next Quarterly Meeting at Broadmoor Hospital on 6 and 7 May are virtually completed and the programme for the Annual Meeting is well in hand. Members' suggestions for topics and speakers for future meetings are always welcome and should be forwarded to me or to the Chairman or Secretary of the Programmes and Meetings Committee-now Drs Graham Lucas and Robin Murray. The College is grateful to these colleagues for the arrangements for the present Quarterly Meeting and for the excellent series of Maudsley Bequest lectures which they have organized.'

\section{PART-TIME TRAINING IN PSYCHIATRY}

The College and the Joint Committee on Higher Psychiatric Training have recently considered part-time training in psychiatry. Although it is recognized that it may not always be possible, it is recommended that the training period should include at least one year of full-time training, though this is not mandatory. The conditions for part-time training are set out under two headings:

(1) General Professional Training in Psychiatry and criteria for entry to the MRCPsych Examination.

(2) Higher Training in Psychiatry.

(1) Approved Training for the MRCPsych Examination (General Professional Training).

(a) Part-time training will be dealt with as an individual circumstance. The Court of Electors through the Dean, will consider each application separately.

(b) Training must be undertaken in an approved post. Supernumerary posts in an approved hospital or training scheme will be acceptable.

(c) The total training period should be equivalent in duration and quality to the normal whole-time training requirement. This does not mean that it is necessary to demand of part-time trainees that they should complete exactly the pro-rata length of training. (Allowance will be made for commitment to the specialty and the use of non-sessional time for such activities as reading and continuing study.)

(d) The Court of Electors, through the Dean, will allow credit for part-time training. This will usually not be less than half-time, though some periods of less than this may be allowed. Part-time training must include all types of clinical experience and responsibility, including residential, 'on-call' and emergency duties in all respects similar to the experience of those undertaking whole-time training, but on a pro-rata basis.

(e) The minimum duration of any one appointment should generally not be less than six months. If there is a break between periods of training, the length of training might need to be increased. This 